\title{
Short-term effects of additional sensory information in mobility and gait speed in older fallers
}

\author{
Isabela Feitosa de Carvalho', Gianluca Loyolla Montanari Leme', Marcos Eduardo Scheicher²
}

\begin{abstract}
Background: Postural balance consists of information emanating from the interaction of visual, somatosensory and vestibular systens. This information is impaired in aging, leading to postural control changes in the elderly, increasing the risk of falls in this population. The postural balance may be improved with the addition of sensory information, such as a subpatelar bandage. Objective: To investigate the effect of using additional sensory information in gait speed and functional mobility of older fallers. Methods: 28 elderly women were evaluated, all were considered fallers. The test Timed Up and Go (TUG) was used to assess functional mobility and $10 \mathrm{~m}$ Test to evaluate the gait speed. The tests were performed with and without the addition of additional sensory information (subpatelar strip). The normality was verified by the Shapiro-Wilk test and the results were compared using paired Student $t$ test and Wilcoxon test. Results: There was significant difference in the TUG $(p=0.0006)$ and in the gait speed $(p=0.004)$ with and without subpatelar strip. Conclusion: The use of additional sensory information increased the gait speed and functional mobility of older fallers.
\end{abstract}

Key-words: Older Fallers, Postural Balance, Proprioception, Mobility Limitation.

\section{INTRODUCTION}

Fall is defined as an unintended episode, which results in a lower position which the individual failed to correct in a timely manner ${ }^{(1-3)}$. Fall down is one of the issues related to the geriatric health of the population ${ }^{(4)}$, considering that $30 \%$ of the older faller at least once a year and $50 \%$ will fall on a recurring basis ${ }^{(5)}$. In addition, it is the 6th leading cause of death in people over 65 and is considered the main cause of morbidity, loss of autonomy and quality of life in aging ${ }^{(6,7)}$. Postural balance is the result of the harmonic interaction between the vestibular, visual and somatosensory systems, and changes in these systems or in the interaction between them increases the risk of falls ${ }^{(8-10)}$. One of the forces that maintain postural control is sensory information, interfering with motor action related to postural control, and it is influenced by motor actions ${ }^{(9-11)}$. Some studies have indicated that sensory information can be used continuously in individuals with proprioceptive deficit with good results in reducing body oscillation and improving mobility ${ }^{(8-14)}$. The first studies by Bonfim and Barela ${ }^{(11)}$, showed the body oscillation reduction in a situation of contact with a touch bar in individuals who had lesions of anterior cruciate ligament ( $A C L)$. Felicio et al. ${ }^{(12)}$ in his study evaluated the use of sensory addition in individuals with Patellofemoral Syndrome, while Carvalho et al. ${ }^{(13)}$ showed an improvement in functional mobility in older ladies fallers and older fallers who do not fall with the use of the sub- patellar. The additional sensory information is also the great importance for healthy individuals, as long as it provides useful information for carrying out the proposed task ${ }^{(8-10)}$.

The first studies using the addition of sensory information proved their efficacy in healthy individuals, but it is of greater relevance in subjects with proprioceptive deficit ${ }^{(9,11,15,16)}$. Therefore, the geriatric population can benefit from the effect of additional sensory information, which is a low-cost tool which may help maintain postural balance and reduce the risk of falls ${ }^{(13)}$.

Although the number of studies with the addition of sensory information has increased in recent years, however there is still discordance results related to the geriatric population with a history of falls. The aim of this study was to investigate the short-term effect of additional subpatellar strip sensory information use on functional mobility and average gait velocity in elderly women with a history of falls. 


\section{METHODOLOGY}

\section{Participants}

Twenty-eight elderly women living in the community of Marília-SP, aged 60 years or older, classified as sedentary according to the Brazilian Society of Sports Medicine ${ }^{(17)}$ were evaluated. The study did not include elderly women with uncorrected visual problems, continuous use of antidepressant and sedative medications, they were unable to maintain orthostatism for at least 90 seconds, on gaiters and with neurological diseases. Cognitive screening was performed by the Mini Mental State Examination (MMSE), and the cut-off score was defined by schooling ${ }^{(18,19)}$. All participants were considered old ladies with self-reported one or more falls occurring in the 12 months prior to the date of the initial evaluation $^{(20,21)}$

The procedures were carried out in the didactic laboratories of the Physiotherapy and Occupational Therapy Building on the campus of the University - UNESP in the Philosophy and Sciences Faculty, Marília, SP. The selected participants were volunteers and signed the Informed Consent Term before data collection. The study was approved (process $n=0982 / 2014$ ) in the Research Ethics Committee of the Philosophy and Sciences Faculty / UNESP / Marília, SP and published in the Brazilian Registry of Clinical Trials- (RBR-54jrwd).

\section{Procedures}

All participants answered a questionnaire with the following items: name, age, schooling, marital status, history of falls, place of fall, consequences of falls, and number of medications for continued use, such as hypertensive medications, metabolic syndrome control, and diabetes, associated diseases.

The evaluation consisted of two situations: 1) normal information condition, without the inclusion of the sub-patellar strip; 2) Additional sensory information condition: with the careful use of the sub-patellar strip, brand Salvape ${ }^{\circledR}$ (SalvaPé Orthopedic Products ${ }^{\circledR}$ ), with a width of $2 \mathrm{~cm}$, placed bilaterally, in orthostatic position. (Figure 1)

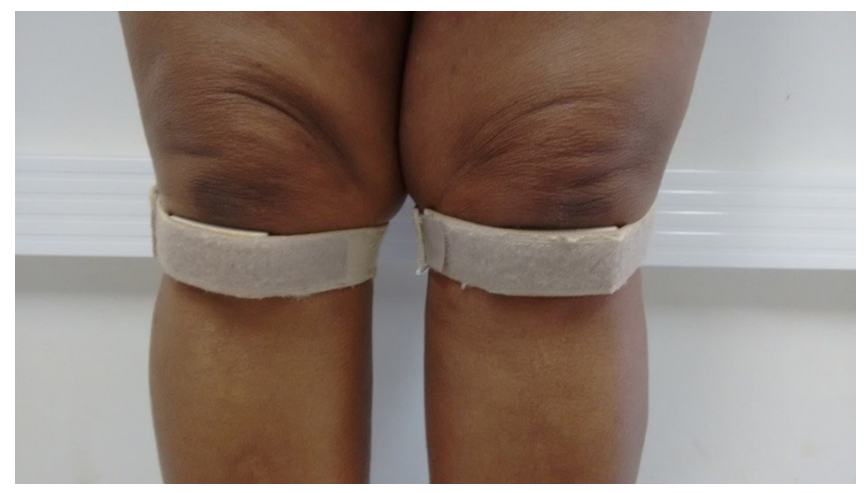

Figure 1: Sub-patellar strip

\section{Functional Mobility Assessment}

The functional mobility was evaluated by the Timed up and Go (TUG) test, measuring in seconds the time spent by the volunteer to get up from a chair, without the help, walk a distance of 3 meters, turn and return to the starting point. At the beginning of the test, the volunteer stays with her back against the back of the chair and, at the end, must lean again. The participant receives the "go" instruction to perform the test and the time must be timed from the command voice until the volunteer again rests her back on the back of the chair. The test should be performed once for familiarization and a second time for taking time ${ }^{(5.23)}$. Even though the use of a cut-off value ${ }^{(24)}$ is not recommended, Schoene et al. ${ }^{(25)}$ indicates the value of 10 s for sedentary elderly, while Alexandre et al. ${ }^{(26)}$ recommends values of $12.47 \mathrm{~s}$ for the Brazilian elderly population.

TUG is widely recommended as a predictor of risk of falls in the elderly, indicating functional mobility deficit, and consequently lower postural balance. Hence, lower values show an improvement in mobility, postural balance, higher walking speed and a lower risk of fall ${ }^{(25)}$.

\section{Average speed gait evaluation (VM)}

The $10 \mathrm{~m}$ walk test was used to evaluate the gait velocity of the elderly women. The usual gait speed is a simple, easy-to-acquire measure and does not require sophisticated equipment. In order to eliminate the acceleration and deceleration factor the participants were asked to start the trek $1.2 \mathrm{~m}$ before timing and finish $1.2 \mathrm{~m}$ later. Three attempts were made to minimize the learning effect, and the shortest time was used for data analysis. Participants received the command "Walk to the next mark at your normal speed as soon you are ready"(27).

\section{Statistical analysis}

The normality of the data was verified by the Shapiro-Wilk test and the comparisons performed by the paired Student $t$ test and Wilcoxon. The level of significance of $p \leq 0.05$ was adopted.

\section{RESULTS}

Table 1 shows the characteristics of the study subjects in relation to age, medication use, MMSE, body mass index and number of falls. All participants used medication, $79 \%$ for systemic arterial hypertension and $75 \%$ to control the Metabolic Syndrome. On the group evaluated, 57\% was classified as recurrent. There was a significant difference in the average walking speed of the elderly in comparison with and without the use of additional sensory information. The values changed from $1.08 \mathrm{~m} / \mathrm{s}$ to $1.14 \mathrm{~m} / \mathrm{s}$, with $\mathrm{p}=0.004$ as shown in Figure 2. The $10 \mathrm{~m}$ walk test data decreased from $9.41 \mathrm{~s}$ to 9.03s, with $p=0.002$ 
Table 1. Sample characteristics

\begin{tabular}{cc}
\hline FALLERS GROUP $(\mathbf{n}=\mathbf{2 8})$ & AVERAGE (DP) \\
\hline AGE (YEARS) & $69.8(6.73)$ \\
No OF FALLS & $1.6(0.78)$ \\
No MEDICATIONS & $3.0(2.32)$ \\
BMI & $29.0(3.51)$ \\
MMSE & $26.0(2.75)$ \\
\hline
\end{tabular}

Note: BMI: body mass index, MMSE: mini-mental state examination.

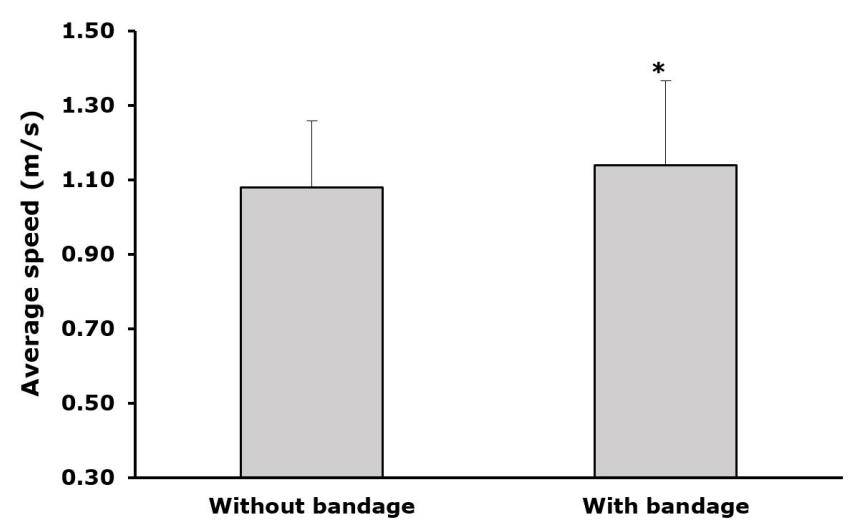

Figure 2: Average walking speed with and without the use of the sub-patellar strip. Note: AS: Average Speed; ${ }^{*} p=0.004$.

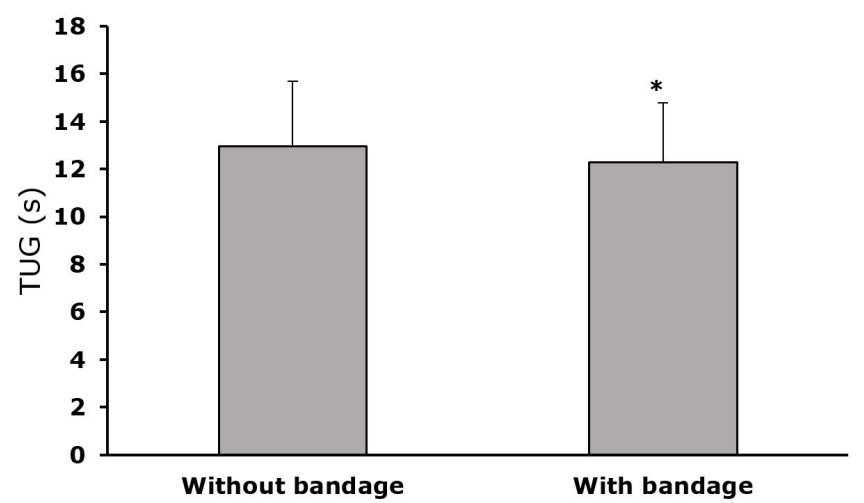

Figure 3: Mean of TUG scores with and without the use of the sub patellar strip. Note: TUG: Timed up and Go. ${ }^{*} \mathrm{P}=0.0006$.

The functional mobility evaluation showed a significant difference with and without the use of the sub-patellar strip, with a reduction in TUG time from $12.95 \mathrm{~s}$ to $12.29 \mathrm{~s}$, with $p=0.0006$ as shown in Figure 3. There was no significant difference between occasional older fallers and recurrent older fallers. It was observed the use of the sub-patellar strip demonstrated beneficial effect in both cases.

\section{DISCUSSION}

The purpose of the present study was to investigate the short-term effect of the use of additional sensory information on walking speed and functional mobility of older fallers. According to the literature, joint sensory information interferes with motor action related to postural balance and, at the same time, influences motor action in obtaining sensory information $^{(9,10)}$. The Central Nervous System (CNS) receives the afferent information from the body and space orientation, and selects effective responses to stabilize the body ${ }^{(11)}$.

The results demonstrated a decrease in TUG time with the use of the subpatellar strip. The lower of the value obtained in the test, the better functional mobility of the individual ${ }^{(22,25)}$. The test is also highly recommended as a predictor of risk of falls, in such way the elderly who has a good TUG score can be considered with low risk of falls, increased functional mobility and reduced balance deficit ${ }^{(25,26)}$. However, it is a simple and easy to perform tool, the TUG test is considered complex for the elderly, as it consists of performing weight transfers, walking and turning to return to the starting point. These tasks require the interaction of neuromuscular components, such as strength, agility and balance. High values in the execution of this test may indicate less postural control, decrease in walking speed, fear of falls and decrease of muscle strength ${ }^{(25,28)}$.

Data from the $10 \mathrm{~m}$ walk test were also reduced (from 9.41s to $9.03 \mathrm{~s}, \mathrm{p}=0.002$ ), corresponding to the increase in mean walking speed (MV) of the evaluated population from $1.08 \mathrm{~m} / \mathrm{s}$ to $1.14 \mathrm{~m} / \mathrm{s}(\mathrm{p}=0.004)$. This result is extremely positive for demonstrating the effect of the sub-patellar strip on the postural balance components. In compliance with the literature, a reduction of $0.1 \mathrm{~m} / \mathrm{s}$ at the mean velocity can increase the risk of falls by $7 \%$ and its consequences, even the risk of death ${ }^{(29)}$.

Conforming to Sustakoski et al. ${ }^{(30)}$, the MV cutoff value was set at $1.13 \mathrm{~m} / \mathrm{s}$ for tests performed using acceleration and deceleration. Values below that stated may indicate a greater risk of falls. The present study showed the efficacy of the subpatellar strip in increasing MV to $1.14 \mathrm{~m} / \mathrm{s}$, suggesting a decrease in the risk of falls in the participants. In geriatric rehabilitation, the increase in MV usually predicts progress in independence and mobility ${ }^{(31)}$, since it improves physical functions, reduces disability and uses medical services ${ }^{(32)}$. The MV evaluation is simple and may indicate a good state of aging, and greater ability in recovery in episodes that the elderly undergoes an overload, such as the fall ${ }^{(25,33,35)}$. The MV is used as a guide to map and categorize the elderly with high and low risk of falls, and it is able to identify the fear of falling present in this population ${ }^{(34)}$.

The mechanism of the sensory information addition action, especially the subpatellar strip, has not yet been fully elucidated. The main hypothesis, found in studies, suggests 
the increase of afferents by constant cutaneous stimulation, greater stimulation to the superficial skin receptors and local receptors, with consequent improvement of the articular proprioceptive response $\mathrm{e}^{(12-16,22)}$.

Older fallers present reduced mobility and are more likely to decrease muscle strength caused by aging and inactivity, with consequent impact on walking and stabilization of the ankle and hip (36). The stimulus increase coming from the sub-patellar strip can favor the kinematics of the knee joint and produce beneficial results in the mobility and walking speed of this population ${ }^{(13,35)}$.

The activated brain areas for postural balance maintenance receive less stimuli in aging, and for this reason they present less activation in these regions ${ }^{(36)}$. The addition of sensory information can increase the stimuli for the less activated regions and thus improving the proprioceptive response in postural control $\left.\right|^{(13,36)}$.

In agreement with Globe et al. ${ }^{(37)}$, the proprioceptive feedback has a strong influence on the maintenance of postural control. When we increase the sensory information, we produce improvement in the proprioception and, consequently, in the postural equilibrium ${ }^{(11-13,36-37)}$.

Research should be done to investigate the effects of the subpatellar strip on postural control, since the scarce number of studies on the subject tackled makes it difficult to apply to larger populations or even other situations where there is altered postural balance. New studies involving the addition of sensory information could be carried out to concretize questions such as the durability of the sensorial stimulus and its effectiveness in activities and training proposed during physiotherapeutic rehabilitations and daily practices. However, the positive results of the present study indicate the possibility of using the subpatellar strip in clinical practices and public health due to the ease of use and low cost.

\section{CONCLUSION}

The use of sub-patellar-type sensory information was effective in increasing mean walking velocity and functional mobility of older fallers These results indicate that additional sources of sensory information may represent an important tool in order to reduce the risk of falls in this population.

\section{AUTHORS' CONTRIBUTION}

IFC: survey of participants, application of evaluations, treatment and data processing, article writing; GLML: application of evaluations, treatment and data processing, article writing; MES: research orientation, statistical analysis, article correction.

\section{CONFLICT OF INTERESTING}

The authors declare no conflict of interest.

\section{AUTHOR DETAILS}

${ }^{1}$ Universidade Estadual Paulista "Júlio de Mesquita Filho" - UNESP, Rio Claro (SP), Brazil.

\section{REFERENCES}

1. Greene BR, O'Donovan A, Romero-Ortuno R, Cogan L, Scanaill CN, Kenny RA. Quantitative falls risk assessment using the timed up and go test. IEEE Trans Biomed Eng. 2010;57(12):2918-26.

2. Herman T, Giladi N, Hausdorff JM. Properties of the "timed up and go" test: more than meets the eye. Gerontology. 2011;57(3):203-10.

3. Pimentel I, Scheicher ME. Comparação da mobilidade, força muscular e medo de cair em idosas caidoras e não caidoras. Rev Bras Geriatr Gerontol. 2013;16(2):251-7.

4. Siqueira FV, Facchini LA, Silveira DS, Piccini RX, Tomasi E, Thumé E, et al. Prevalence of falls in elderly in Brazil: a countrywide analysis. Cad Saúde Pública. 2011;27(9):1819-26.

5. Ansai JH, Glisoi SFN, Oliveira T, Soares AT, Cabral KN, Sera CTN, et al. Revisão de dois instrumentos clínicos de avaliação para predizer risco de quedas em idosos. Rev Bras Geriatr Gerontol. 2014;17(1):177-89.

6. Gschwind YJ, Kressig RW, Lacroix A, Muehlbauer T, Pfenninger B, Granacher $U$. A best practice fall prevention exercise program to improve balance, strength/power, and psychosocial health in older adults: study protocol for a randomized controlled trial. BMC Geriatr. 2013;13:105.

7. Hernandez SSS, Coelho FGM, Gobbi S, Stella F. Efeitos de um programa de atividade física nas funções cognitivas, equilíbrio e risco de quedas em idosos com demência de Alzheimer. Rev Bras Fisioter. 2010;10(1):68-74.

8. Barela JA. Estratégias de controle em movimentos complexos: ciclo percepção-ação no controle postural. Rev Paul Educ Fís. 2000;supl 3:7988.

9. Timmann D, Horak FB (2001) Perturbed step initiation in cerebellar subjects: 2. modification of anticipatory postural adjustments. Exp Brain Res. 2001; 141(1):110-120.

10. Toledo DR, Barela JA. Diferenças sensoriais e motoras entre jovens e idosos: contribuição somatossensorial no controle postural. Rev Bras Fisioter. 2010;14(3):267-275.

11. Bonfim TR, Barela JA. Efeito da manipulação da informação sensorial na propriocepção e no controle postural. Fisioter Mov. 2007;20(2):107-17.

12. Felicio LR, Masullo Cde L, Saad MC, Bevilaqua-Grossi D. The Effect of a Patellar Bandage on the Postural Control of Individuals with Patellofemoral Pain Syndrome. J Phys Ther Sci. 2014;26(3):461-4.

13. Carvalho IF, Bortolotto TB, Fonseca LCS, Scheicher ME. Uso da bandagem infrapatelar no desempenho físico e mobilidade funcional de idosas com história de quedas. Rev Bras Geriatr Gerontol. 2015;18(1):119-27.

14. Botelhos DC, Bonfim TR. Influência da informação sensorial adicional no treinamento sensório-motor. Fisioter Pesqui. 2012;19(3):268-74.

15. Callaghan MJ, Selfe J, Bagley PJ, Oldham JA. The effects of patellar taping on knee joint proprioception. J Athl Train. 2002;37(1):19-24.

16. Jerosh J, Prymka M. Knee joint proprioception in normal volunteers and patients with anterior cruciate ligament tearstaking special account of the effect of knee bandage. Arch Orthop Trauma Surg. 1996;115(3-4):162-6.

17. Nóbrega $A C L$, Freitas EV, Oliveira MAB, Leitão MB, Lazzoli JK, Nahas RM, et al. Posicionamento oficial da Sociedade Brasileira de Medicina do Esporte e da Sociedade Brasileira de Geriatria e Gerontologia: atividade física e saúde no idoso. Rev Bras Med Esporte. 1999;5(6):207-11.

18. Brucki SMD, Nitrini R, Caramelli P, Bertolucci PHF, Okamoto IH. Sugestõespara o uso do mini-exame do estado mental no Brasil. ArqNeuroPsiquiatr. 2003;61:777-81.

19. Reis LA, Torres GV, Araújo CC, Reis LA, Novaes LKN. Rastreamento Cognitivo de idosos institucionalizados no município de Jequié-BA. Psicol Est. 2009;14(2):295-301.

20. Gonçalves DFF, Ricci NA, Coimbra AMV. Equilíbrio funcional de idosos da comunidade: comparação em relação ao histórico de quedas. Rev Bras Fisioter. 2009;13(4):316-23.

21. Sai AJ, Gallagher JC, Smith LM, Logsdon S. Fall predictors in the community dwelling elderly: a cross sectional and prospective cohort study. J Musculoskelet Neuronal Interact. 2010;10(2):142-50. 
22. Podsiadlo D, Richardson S. The Timed "Up \& GO": a test of basic functional mobility for frail elderly persons. J Am Geriatr Soc. 1991;39:142-8.

23. Schoene D, Wu SM, Mikolaizak AS, Menant JC, Smith ST, Delbaere K, et al. Discriminative ability and predictive validity of the timed up and go test in identifying older people who fall: systematic review and meta-analysis. J Am Geriatr Soc. 2013;61(2):202-8.

24. Rose DJ, Jones CJ, Lucchese N. Predicting the probability of falls in community-residing older adults using the 8-Foot Up and Go: a new measure of functional mobility. J Aging Phys Act. 2002;10(4):466-75.

25. Singh KAD, Pillai GKS, Tan TS, Suzana S. Association between physiological falls risk and physical performance tests among community-dewling older adults. Clin Interv Aging. 2015;10:1319-26.

26. Alexandre TS, Meira DM, Rico NC, Mizuta SK. Accuracy of timed up and Go test for screening risk of falls among community-dwelling elderly. Rev Bras Fisioter. 2012;16(5):381-8.

27. Abreu SSE, Caldas CP. Velocidade de marcha, equilíbrio e idade: um estudo correlacional entre idosas praticantes e idosas não praticantes de um programa de exercícios terapêuticos. Rev Bras Fisioter. 2008;12(4):324-30.

28. Virtuoso JF, Gregório LPP, Medeiros PA, Mazo GZ. The "Timed up and Go" in the prediction and explanation of falls in old people practicing physical exercises. Rev. Bras. Cineantropom. Desempenho hum. 2014; 16(4):381-9.

29. Hardy ES, Perera S, Roumani YF, Chandler JM, Stundenski AS. Improvement in usual Gait Speed predicts better survival in older adults. J Am Geriatr Soc. 2007;55(11):1727-34.
30. Sustakoski A, Perera S, VanSwearingen JM, Studenski AS, Brach JS. The impact of resting protocol on recorded gait speed. Gait Posture. 2015;41:329-31.

31. Santos AS, Tribess S, Pinto LLT, Ribeiro MCL, Rocha SV, Virtuoso Júnior JS. Velocidade de caminhada como indicador para a incapacidade funcional em idosos. Motricidade. 2014;10(3):50-60.

32. Pamoukdjian F, Paillaud E, Zelek L, Laurent M, Lévy V, Landre T, et al. Measurement of gait speed in older adults to identify complications associated with frailty: a systematic review. J Geriatr Oncol. 2015;6(6):48496.

33. Verghese J, Holtzer R, Lipton RB, Wang C. Quantitative gait markers and incident fall risk in older adults. J Gerontol Ser A Biol Sci Med Sci. 2009;64(8):896-901.

34. Tapajós DM, Maciel ACC. A velocidade de marcha pode identificar idosos com medo de cair? Rev Bras Geriatr Gerontol. 2013;16(1):71-80.

35. Marques NR, LaRoche DP, Hallal CZ, Crozara LF, Morcelli MH, Karuka $\mathrm{AH}$, et al. Association between energy cost of walking, muscle activation, and biomechanical parameters in older female fallers and non-fallers. Clin Biomech (Bristol, Avon). 2013;28(3):330-6.

36. Goble DJ, Coxon JP, Van Impe A, Geurts M, Doumas M, Wenderoth N, et al. Brain activity during ankle proprioceptive stimulation predicts balance performance in young and older adults. J Neurosci. 2011;31(45):16344-52.

37. Goble DJ, Coxon JP, Wenderoth N, Van Impe A, Swinnen SP. Proprioceptive sensibility in the elderly: degeneration, functional consequences and plastic-adaptive processes. Neurosci Biobehav Rev. 2009;33(3):271-8. 